\title{
Changing Patterns of Wealth Distribution: Evidence from Ghana
}

\author{
Abena D. Oduro \\ Department of Economics \\ University of Ghana \\ P.O. Box LG57 \\ Legon, Ghana \\ Abena.oduro@gmail.co \\ Cheryl Doss \\ Oxford Department of International Development \\ University of Oxford \\ 3 Mansfield Road \\ Oxford, UK \\ OX1 3TB \\ Cheryl.doss@qeh.ox.ac.uk
}

Forthcoming, Journal of Development Studies

Keywords: gender, asset, asset accumulation, inheritance, structural transformation

Acknowledgements: The authors wish to thank Carmen Diana Deere and Douglas Gollin for their comments on this paper and Jana Bischler for excellent research assistance. 


\section{Changing Patterns of Wealth Distribution: Evidence from Ghana}

\section{Introduction}

A largely unexplored feature of structural transformation is the shifting composition of assets, corresponding to the changing sectoral composition of output. As economies develop, there is a tendency for wealth to shift from land - normally the most important form of wealth in poor agrarian economies - to a wider range of assets, including housing, financial assets and business assets. This pattern was apparent in the US and Britain in the late nineteenth century; during this period, financial assets became a larger component of wealth, and land became correspondingly less important (Keister, 2000; World Bank, 2011). The same pattern appears to hold broadly today in developing countries. According to one set of detailed estimates, natural capital (including agricultural land, forests, and mineral resources) accounted for 30 percent of the total wealth of low income countries in 2005. By contrast, natural capital accounted for only 25 percent of the wealth of low-middle income countries, 15 percent of the wealth of uppermiddle income countries, and 2 percent of the wealth of high income countries (World Bank 2011, Table 2.3, p. 30).

A related feature is that historically, as the composition of wealth changed, the share of assets owned by women has also increased. A simple explanation is that as sources of wealth beyond land become available, it is easier for a wider group of people, including women, to accumulate them. Inheritance patterns of financial assets tend to be more gender neutral than inheritance patterns for land (Deere and Doss, 2006). In many economies, it has been both easier and socially more acceptable for women to own non-farm businesses than to own agricultural 
land (Green and Owens, 2003; Rutterford and Maltby, 2006). In such contexts, economic growth may reduce some of the constraints on women's opportunities to accumulate assets.

Women's ownership of assets, particularly productive assets, and the accumulation of wealth, is important for several reasons. First, as a normative matter, men and women should have equal opportunities to acquire and retain assets. In addition, wealth and control over productive assets are empowering for women and may increase their bargaining power within households and the community (Doss, 2013). Empirical evidence shows that women's ownership of assets is correlated with positive outcomes, including better health and nutrition outcomes for their children (Allendorf, 2006), reduced exposure to domestic violence (Panda and Agarwal, 2005; Friedemann-Sanchez and Rodrigo, 2012; Oduro, Deere and Catanzarite, 2015) and higher proportions of household expenditure on food and education (Doss, 2006).

The evidence on these associations between structural change and women's increased asset ownership comes primarily from developed country contexts where structural transformation has been observed over a relatively long time horizon. Much of the evidence is also drawn from macro sources and national aggregate statistics. This paper contributes to the literature by analysing whether the same patterns hold in micro data from Ghana, a country that is now in the early stages of structural transformation. Do we see similar shifts in the patterns of asset holdings? And to what extent do women benefit from these changes? Structural transformation is happening at a rapid pace in many countries. Because increased gender equity in asset holding is often a key policy goal, it is important to understand the extent to which this is occurring with structural transformation.

The two decades from 1990-2013 were a period of rapid economic growth for Ghana, with substantial movement of people out of the agricultural sector and rapid urbanization. 
Although many aspects of Ghana's economic transformation have been analysed, there has been little documentation of the patterns of wealth accumulation over this period.

Ghana is a particularly interesting context in which to study the changing patterns of asset ownership, for two reasons. First, we have high-quality data from nationally representative household surveys, stretching back twenty years, on the composition of household asset holdings. This is an unusually rich data source for a developing country. A second reason for focusing on Ghana is the richness of the data in terms of sex disaggregation of asset holdings; the data identify individual, not just household, holdings of land, businesses, and savings. In addition, in Ghana, most assets are owned individually, rather than held jointly by couples or others (Doss, et al., 2014). This makes it easier to look specifically at women's ownership of assets and how it has changed over time.

This paper contributes to the literature by examining how the patterns of asset holdings have changed during two decades of economic growth in Ghana. The available data allow us to consider two questions: how the composition of household wealth has changed and how women's share of wealth has changed. We find that land is decreasing as a share of wealth over this period; the share of wealth held in housing and financial assets has increased, although the latter increase is smaller than would be expected. Overall, women's share of wealth in Ghana has increased over this period.

\section{Structural Transformation and the Composition of Household Wealth}

Structural transformation is defined as the "reallocation of economic activity across the broad sectors agriculture, manufacturing, and services" (Herrendorf et al., 2014, p. 855). Historically, that has meant a shift from agriculture to manufacturing and then to services. The 
process of structural transformation may be triggered by an increase in labour productivity in agriculture, which makes possible the release of labour to industry and services without a decline in agricultural output (Gollin, et al., 2002). Structural transformation can also occur because of an expansion in manufacturing and the concomitant increase in the demand for labour. When the genesis of structural transformation is either or both of these processes, the movement of labour is from agriculture into manufacturing and eventually services. This is the path that was taken by present-day industrialised countries.

Africa's experience with structural transformation has not necessarily conformed to this pattern. Enacheet al. (2016) identify two paths of structural transformation in Africa. One is the movement from agriculture into a mixture of sectors. The second involves movement directly from agriculture into services - often non-tradable services. For example, a natural resource boom can lead to increased spending on imported manufactured goods thus creating conditions for the emergence of a services sector (Gollin et al., 2016). Policies biased towards the urban population such as excessive taxation of agriculture and food subsidies can pull labour out of agriculture and into the services sector (Osei and Jedwab, 2017).

The shift out of agriculture is visible in cross country comparisons of the share of wealth held in agricultural land. The value of cropland and pasture land as a share of total wealth shows a strong negative relationship with real per capita GDP (see figure 1). Richer countries have a much smaller proportion of their wealth in the form of land.

Moving from national aggregates to more detailed data from household surveys, we find similar patterns in three countries at varying levels of economic development and structural transformation, in data collected through the Gender Asset Gap Project (GAGP). Ownership data was collected on a full range of household assets in 2010 in Ghana, Ecuador, and the state of 
Karnataka, India. The GAGP data for Ghana will be analysed in the later part of this paper. Ecuador is a relatively urbanised country with a human development index (HDI) rank of 77 in 2010 and gross national income (GNI) per capita in purchasing power parity dollars of 7,931 (UNDP, 2010)... Most wealth (62\%) is held in the form of the family's primary residence. This is followed by other real estate (10\%), consumer durables (9\%), non-agricultural businesses (8\%), and agricultural lands (7\%) (Deere and Díaz, 2011). The importance of consumer durables in Ecuador suggests that this may be an important form of assets as countries urbanize. Yet, they are not included as assets in most analyses. Although Ecuador has undergone some structural transformation, little of the wealth is in the form of financial assets.

India ranked 119 on the HDI scale in 2010 and has a per capita GNI in purchasing power parity dollars of 3,337. For Karnataka, the analyses were done separately for rural areas, urban areas, and the urban centre Bengaluru (Swaminathan et a., 2011). In rural areas, land comprises 62 per cent of household wealth and the principal residence 25 per cent; thus, the remaining categories are all minimal. In urban areas, we see a shift away from land (20\%) to the principal residence (53\%) and other real estate (12\%). In the capital, Bengaluru, the principal residence is 79 per cent of household wealth. As expected, we see very large differences in the composition of assets across locations within India and land is less important household asset portfolios in Ecuador than it is in India. Overall, the historical and cross-country patterns suggest that the composition of asset holdings will change through the period of structural transformation.

\section{Structural Transformation, Asset Accumulation, and Gender}

The relationship between structural transformation and asset accumulation depends upon the factors driving the process of structural transformation. Structural transformation based on 
increased agricultural productivity and /or expansion in manufacturing is expected to be growth enhancing, therefore presenting opportunities for asset acquisition. Structural transformation that moves people out of agriculture into the services sector may provide fewer such opportunities.

Although theory does not offer specific predictions, we conjecture that structural transformation in the context of a rapidly growing low-income economy might plausibly lead to changes in asset composition. Savings would be expected to increase with the rise in incomes, thus increasing the importance of financial wealth in asset portfolios when there is growth enhancing structural transformation. Rising incomes and urbanization would be expected to be accompanied by a rise in home ownership and improvements in housing quality, particularly if the structural transformation is accompanied by a growing middle class. Consumer durables will also become important. A critical determining factor will be urbanization and the availability of electricity - which would be expected to increase demand for electrical appliances.

Within the various processes of structural transformation, the opportunities for asset accumulation, through purchase, inheritance, and marriage, may differ for men and women. Structural transformation will have direct implications for asset acquisition through purchase; the influence on acquisition through inheritance and marriage may not be immediate.

Structural transformation that is growth enhancing will improve incomes of individuals and households and be associated with an increase in the ability to save and purchase assets. However, because women and men have different employment rates and women tend to be concentrated in low wage employment, they may be disadvantaged in the market. In addition, the process of structural transformation may involve different rates of exit from agriculture for women and men and different rates of absorption into high productivity sectors. 
Inheritance regimes inform who inherits property s. The laws and social norms may be biased against wives and daughters. In addition, the marital regime prescribes the extent to which property within marriage is considered jointly owned or whether it remains the individual property of the husband or wife. Marital regimes that treat all property acquired while married as the joint property of both spouses tend to have higher levels of asset ownership by women (Deere et al., 2013).

Institutional reforms, such as changes in the laws around women's property rights, may affect women's accumulation of assets. The Married Women's Property Acts in the US increased women's rights to own property and (Shammas, 1993) and similar Acts in the UK changed the composition of women's asset holdings (Coombs, 2006). Recent changes in the Hindu Succession Act in India increased the likelihood of daughters inheriting joint family property, although sons continue to be favoured (Deininger, Goyal and Nagarajan, 2013).

The shift in employment from agriculture may have no immediate bearing on laws, rules, norms and practices that shape the marital and inheritance regimes. However, urbanization and rising incomes can impact aspirations and expectations, creating conditions for changes in these laws, rules, norms and practices over the long term.

Much of the empirical work on women's wealth categorizes households by the sex of the head (Paxton, 2009) or compares households headed by a single individual with those headed by a couple (e.g. Schmidt and Sevak, 2006; Rossi and Sierminska, 2015). However, female-headed households tend to be different from male-headed households in many respects; they are generally smaller; have few, if any, adult men; and tend to be poorer. Thus, the comparison masks many of the differences between men and women more generally and ignores the majority of women who live in households that are defined as male headed. 
Very few analyses have individual level asset data across a range of assets, either to consider the share of assets owned by women or whether the composition of assets held differs by sex. Using estate duty data from the US, Shorrocks (1982) does not find differences in portfolio composition by sex, but he does not provide information on women's share of assets. In Karnataka, India, women only own 19 per cent of household gross physical asset wealth (Doss et al., 2014). In Ecuador, where there is no significant gender gap in the value of household gross physical asset wealth, the asset portfolios of men and women differ, with men's portfolios being much more diverse that women's (Deere and Contreras Diaz, 2011).

In general, increased access to financial assets and changes in legal frameworks have been two of the factors that have benefitted women. We expect to see women's share of asset ownership increasing with structural transformation. We recognise, however, that the pace of institutional reforms and change in attitudes towards women owning assets will be a moderating influence on the effect of structural transformation on women's asset ownership.

\section{Ghana: Context and Background}

. Since the beginning of the 1990s Ghana has posted fairly robust growth rates. Growth rates in the 1990s followed a fluctuating pattern, beginning in 1990 with a growth rate of 3.3 per cent and ending in 1999 with a rate of 4.4 per cent. The period 2000 to 2006 was one of continuously increasing growth rates from 3.7 per cent to 5.9 per cent. Between 2007 and 2011, the cyclical pattern of growth rates returned, although the overall trend was upwards, peaking at 14 per cent in 2011 when oil production began. Growth rates declined after that to 7.3 per cent in 2013. Growth of output has exceeded that of population, translating into positive and generally 
rising per capita growth rates. On average, per capita income growth rates increased by about 0.53 per cent per annum during the period 1990-2014.

Revised gross domestic product figures, as a result of the rebasing of the economy in 2010, revealed that Ghana had attained lower middle-income status in 2007. Ghana's economy has undergone structural transformation, with movements out of agriculture primarily into services rather than manufacturing, following the second path prevalent in Africa described above. Agriculture's share of gross domestic product (GDP) declined from 45 per cent to 24 per cent between 1990 and 2012 (Table 1). The share of manufacturing in GDP remained fairly constant, averaging about 10 per cent between 1990 and 2006 and then decreasing to 6 per cent in 2012. Although manufacturing decreased, overall the industrial sector's share increased, driven largely by the production of oil and gas beginning in 2011 and the expanding construction sector. The services sector also expanded quite rapidly, with its share of GDP rising to 47 per cent in 2012 from 38 per cent in 1990 (Table 1).

The changes in the structure of production have been accompanied by shifts in employment. Agriculture's share of employment declined over the period (Table 1). The service sector's share of employment increased by 15.4 percentage points compared to an increase of 1.5 percentage points for industry.

Ghana is also experiencing rapid urbanization. ${ }^{i}$ The urban population has increased steadily from 32 per cent of the total in 1984 to about 44 per cent in 2000 and about 51 per cent in 2010 .

In the midst of these changes, women's labour force participation has been fairly stable at about 75 per cent in the last two decades. Over the forty-year period beginning in 1970, the share of employed women who work in agriculture has tended to be lower than that for men 
while the share of employed women working in the services sector, particularly wholesale and retail trade, has tended to be higher than that for men (Ghana Statistical Service, 2005). ${ }^{\text {ii }}$ The share of both men and women employed in agriculture dropped 17-18 percentage points between 1992 and 2013 (Table 1). By 2013, 47 per cent of working women and 34 per cent of workingmen were employed in the services sector.

Labour productivity in the agriculture sector in Ghana has historically been lower than in the other sectors (de Vries, et al., 2015; Osei and Jedwab, 2017). Structural transformation has involved reduction in the share of employment in the sector with the lowest labour productivity. Labour, however, is not concentrated in the sector with the highest labour productivity, which is industry. It is concentrated in the services sector which has high, but declining productivity (de Vries et al., 2015). The movement out of agriculture, particularly by women, could provide opportunities to earn higher incomes, however, women are employed predominantly in the wholesale and retail sector. Labour productivity in this sector has been lower than the average for the services sector and has been on the decline (de Vries et al., 2015). Employment in this sector is composed largely of own-account workers with unstable incomes. Thus, even though women are moving out of agriculture, they are not necessarily earning higher wages and increasing their ability to purchase assets.

Changes have also occurred in women's access to assets through inheritance in Ghana. Ghana has a pluralistic legal system comprising formal legal laws and customary laws and practices. The Wills Act of 1971 provides guidelines on how wills are to be prepared and administered but is silent on the distribution of assets by sex of surviving children. The Intestate Succession Act of 1985 provides for children and surviving spouses to inherit a portion of the self-acquired property of someone who dies intestate. 
However, customary law and practices, which vary across ethnic groups, usually determine the distribution of property. Ghana has two major systems of inheritance. In patrilineal systems, children inherit from their fathers, whilst in matrilineal systems they inherit from their maternal uncles. In neither system do spouses inherit from one another. Among many patrilineal groups, sons tend to be favoured in the distribution of fathers' assets whilst mothers' property is equally shared. Among some patrilineal groups, women cannot inherit land (Oduro et al., 2010). Inheritance practices are changing over time and the Intestate Succession Act of 1985 has played a role in supporting some of these changes (Quisumbing et al., 2001; Oduro et al., 2010).

The marital regime under customary law is that of separation of property. Marriage does not confer rights to the spouse's property. The Matrimonial Causes Act of 1971 does not provide explicit guidelines on how properties are to be distributed on divorce, leaving this to the determination of judges. Until recently, on divorce, women who made claims to property acquired during the subsistence of the marriage had to prove that they had made substantial financial contribution to its acquisition. The lacunae in the formal legal regime are addressed by Article 22 of the 1992 Constitution of the Republic of Ghana that requires parliament to enact legislation regulating the property rights of spouses. Although this legislation has not yet been enacted, a Property Rights of Spouses Bill has been placed before Parliament. In the meantime, judgments in the courts have begun to recognize the contribution of women's unpaid work in the home to the acquisition of their spouses' property (Deere et al., 2013). These changes in the legal institutions and the social norms over this period have opened some new opportunities for women to acquire assets.

Economic transformation in Ghana provides mixed opportunities for women to acquire assets. Despite the economic growth of the last two decades, women's continued concentration 
in vulnerable employment, i.e. own account workers and unpaid family workers, limits their ability to purchase assets. Traditional inheritance norms still restrict women's ability to inherit assets such as land and livestock despite the legal changes. However, the rapid urbanization coupled with the expansion of the financial sector, particularly in urban locations means that new opportunities may become available.

\section{Data and Methods}

We rely on two sources of data for this analysis. The Ghana Living Standards Surveys (GLSS) are nationally representative household surveys collected regularly by the Ghana Statistical Service. We use four rounds of data, from 1991/1992 to 2012/2013. The surveys collected data from 4523 households (1991/1992), 5998 households (1998/1999), 8687 (2005/2006) and 16772 households (2012/2013). Although there are some slight changes in the surveys over this period, the wording on the questions about assets is consistent. ${ }^{\text {iii }}$

These surveys have detailed data on asset holdings at the household level including information on the value of land, housing, other real estate, consumer durables, business assets, livestock, savings, financial shares, and agricultural equipment. In addition, the surveys identify the individual holder of the land and the owner of all businesses and financial assets. Thus, the values of these assets can be disaggregated by gender. The GLSS surveys are not a panel and do not follow the same households over time. Thus, we analyse the overall patterns of asset holding, in terms of the composition of assets, over time.

The second source of data is the Gender Asset Gap Project (GAGP) Ghana survey. The project conducted a nationally representative individual level asset survey in 2010, composed of 2170 households. This is the first nationally representative survey in Africa with such detail. 
The sampling frame is based on that of the GLSS. In this analysis, we use the household asset inventory which detailed all assets owned by anyone in the household, the identity of the owner (with provision for recording of joint ownership) and the asset value. The only assets not detailed in the household inventory are financial assets. Questions about financial assets were asked to two household members who provided information only about their own. The GAGP household inventory collected data on the same categories of assets as the GLSS. .

Most assets in Ghana are individually owned, including about 93 per cent of privately owned agricultural land and 96 per cent of businesses (Oduro et al., 2011). It is straightforward to allocate the value of the asset to its owner when it is individually owned. In the instances of joint ownership of an asset, we have assumed that each owner has equal claim to the asset and distribute the value equally among them.

There are a few key differences between the GLSS surveys and the GAGP survey. For agricultural land, the GLSS asks about the value of all land held by households. This includes both privately owned land and family land. The latter is land under customary tenure where a household has some claims but not full ownership rights. In the GAGP survey, the value of land is only asked for privately owned land. And while one household member in the GLSS provides information on everyone's financial assets, in the GAGP, we have information only for the two respondents who each detail their own.

In the analysis that follows, we report gross wealth values rather than net values. Neither the GLSS nor the GAGP surveys collected comprehensive data on indebtedness. ${ }^{\text {iv }}$ However, indebtedness among households in Ghana is relatively low (Grown et al., 2015). A very small fraction of land and buildings that are purchased or buildings that are constructed by their owners are financed using debt (Grown et al., 2015). 
We calculate the per cent of total household wealth held in each asset category for each survey round. Thus, we focus on the proportions of household wealth held in different forms, rather than the total wealth levels. Women's share of asset ownership is calculated as the sum of the value of the asset owned by all women divided by the sum of the value of the asset across all owners in all households.

Because we consider the percentage of asset wealth held in different forms at particular moments in time, we do not have to worry about deflating. The patterns we present here incorporate both the impacts of the changes in the composition of the physical and financial assets as well as changes in their relative value over time.

We begin by presenting evidence on the composition of household asset wealth over time. We then present evidence on women's share of land, business and financial wealth over time using data from the four GLSS surveys. This is followed by a discussion on the composition of asset wealth of women and men using the GAGP data.

Data on asset values from household surveys are noisy measures. ${ }^{v}$ All of these surveys use values as reported by the respondent. Particularly in times of rapid economic change, people may not know the current value of their assets. In addition, the shares of any one asset category may be affected by reporting discrepancies in any other. Thus, we focus on the general patterns of change over the period.

\section{Distribution of Household Asset Holdings over Time}

The overall patterns observed in the Ghanaian data are generally consistent with the expectations of what we would see through structural transformation. The importance of land in households' wealth portfolios has declined steadily over this period, from 35 per cent in 
1991/1992 to 23 per cent in 2012/2013. The decline was most rapid between 1991/92 and 1998/99 (see Table 2). However, financial assets remain a relatively small proportion of household wealth. Financial savings comprise just over 5 per cent of households' wealth portfolios in the most recent period, although there has been an increase in their share over time. Shares in companies have remained a minuscule proportion of household wealth at 0.2 per cent. (In this section, we collapse savings and shares into a single category of financial assets; however, only the savings data is disaggregated by sex).

The share of wealth held as housing (the primary residence) increased over the period from about 32 per cent to about 39 per cent, although there was a drop in 1998/99. The share held in consumer durables went consistently up, rising by four percentage points to 13 per cent in 2012/13.

The 1998/99 survey was a bit of an anomaly. The share of wealth held in the form of housing was below the overall trend and the shares of business assets and livestock was above. Household Asset Holdings by Location

Comparisons of rural and urban areas provide some insights into the patterns of structural transformation and asset holdings. Generally, the patterns are as we would expect. Land, other real estate and livestock feature much more prominently in rural wealth portfolios than they do those of urban households (Table 3). Housing and consumer durables consistently comprise the largest share of assets in the urban portfolio. Wealth held in the form of livestock comprises a larger share of rural portfolios whilst the share of business assets is larger in urban portfolios. Business opportunities with higher returns and financial institutions tend to be located in urban areas and we see this reflected in the larger shares held in financial assets in urban areas than in rural areas. The within location changes in the patterns of wealth held over time are less dramatic 
than the differences between the two areas. The overall trends in composition of household wealth are consistent with a story of people moving from rural to urban areas and shifting to an urban bundle of assets.

\section{Explaining the trends}

Looking at the shifting composition of household assets over time, the importance of land in the wealth portfolio has declined as anticipated. This is largely because of the increased opportunities to earn incomes outside of agriculture and to hold wealth in different forms.

Land and housing make up the largest share of households' wealth portfolios. Purchase is becoming of increasing importance in the acquisition of land, particularly urban land (Oduro, Baah-Boateng and Boakye-Yiadom, 2011). Unfortunately, the GLSS data does not have information on modes of acquisition which makes it impossible to disentangle the effect of rising incomes on the share of land in household asset portfolios. Most assets are owned outright since credit is not an important source of financing asset acquisition.

The increasing share of housing wealth in households' asset portfolios is a reflection of both increased incidence of home ownership and rising housing values. The incidence of owner occupancy has increased from 37 per cent in 1991/1992 to about 46 per cent in 2012/2013.

Rising incomes and urbanisation can explain the increasing share of consumer durables in households' asset portfolios. The proportion of households that own consumer durables has risen since 1991/1992 from 77 per cent to 96 per cent in 2012/2013. Growth and development have been accompanied by the acquisition of increasingly more valuable and sophisticated consumer durables such as televisions, refrigerators, cookers, cars and DVDs. For example, the incidence of ownership of refrigerators and freezers and televisions increased five-fold between 1991/1992 
and 2012/2013. By 2012/2013 about 60 per cent of households owned televisions and 42 per cent owned refrigerators or freezers. Consumer durables are not only consumption goods; they may be used to supplement an income and they can be sold during times of crisis to smooth consumption (Doss, et al., 2015). Rising incomes and the spread of electricity can explain the rise of consumer durables in wealth portfolios, particularly in urban areas.

The share of financial savings in households' asset portfolios has increased but from a very low base and remains low. Yet, more households are holding savings. Overall, between 1991/1992 and 2012/2013 the percent of urban households with savings increased by 18 percentage points and the share of rural households by 12 percentage points.

Developments in the supply side of the financial sector can explain this increase. The number of financial institutions increased during the period and this is reflected in the financial and insurance sector's share of GDP increasing from 2.7 per cent of GDP in 2006 to 6.5 per cent in 2013 (Ghana Statistical Service, 2015). Yet, the coverage of commercial banks is low at 5.4 per 100,000 adults (Demirguc-Kunt et al., 2015). This is higher than the average of 3.5 for subSaharan African countries but lower than the average of 7.2 for lower middle-income countries overall. The stock exchange was established in 1989 and by December 2015 had 42 companies listed.

The requirements to open a savings account exclude large segments of the population from the formal financial sector. For example, a national identity card or a utility bill is required to open an account and some institutions require a guarantor who is a client. Considering that Ghana does not have universal coverage of electricity and water, and most people do not have a passport or driver's licence, these requirements can exclude a large proportion of potential customers. 
In addition, the rates of return on financial assets in Ghana tend to be low. Savings deposits with commercial banks may even yield a negative return. Although savings rates have ranged between 2 per cent and 18 per cent, they were lower than the inflation rates of 18.1 per cent in 2008, 16 per cent in 2009 and 8.6 per cent in 2010 (Bank of Ghana, 2012). Rates on Treasury bills issued by the Government of Ghana are typically higher than savings deposit rates and inflation rates; for example the 91-day Treasury bill rates were 24.7 per cent, 23.7 per cent and 12.3 per cent in December 2008, 2009 and 2010 respectively (Bank of Ghana, 2012). However, returns on assets such as housing tend to be higher. For six of the twelve years from 1999 and 2010, the rate of increase in housing prices was higher than 91-day Treasury bill rates. ${ }^{\mathrm{vi}}$ Thus, while the opportunities for holding financial assets are expanding, they are still relatively limited and many people choose to invest elsewhere.

There is not a clear story for why the livestock shares of wealth have fluctuated. The number of livestock held have increased steadily over the period (Ministry of Food and Agriculture, 2011). Livestock prices fluctuate both seasonally and over time, which may influence the values reported.

The slight decline in the share of business wealth has occurred at the same time as the incidence of business ownership among households has risen. The majority of businesses either have no workers or employ less than five workers. The industrial census of firms conducted in 2003 found that about 54.5 per cent of firms in the mining and quarrying, manufacturing and utilities sectors employed less than 5 people. Thus, business wealth may be declining in importance because despite the shift out of agriculture, business ventures in the non-agriculture sector tend to be small. 


\section{Women's Share of Asset Wealth}

The historical pattern suggests that structural transformation of the economy presents new opportunities for women to increase their asset ownership. Yet, as noted above, there are still many constraints facing women in their accumulation of assets in Ghana. Thus, it is useful to look at the data on the share of each type of asset held by women. The discussion of the trends over time focuses on land, business assets, and savings, since these are the three assets that can be disaggregated by sex in the GLSS.

Table 4 presents the share of land, savings, business and total wealth that is held by women over time. Women consistently own a lower share of wealth held in the form of each of these assets compared to men. However, women's share of wealth from each of these assets is substantially higher in 2012/2013 than in 1991/1992. In the earliest period, women owned 14.2 per cent of the wealth held in these asset categories, while men owned the remaining 85.8 per cent. By 2012/2013, women's share had increased to 23.9 per cent of the wealth. Of the three assets for which individual data is available over time, women's share of household asset wealth is highest for savings (31.6\%). Yet, as we saw earlier, a relatively small amount of total wealth is held in the form of savings.

\section{Women's Share of Asset Wealth by Location}

We saw above that the change in the composition of assets within locations over time was relatively small. Instead, the larger story is due to migration from rural to urban areas. Yet, in both locations, we see an overall increase in the share of wealth held by women.

Women's share of land wealth among urban households has increased steadily over time - more than tripling over the period. This contrasts with women's share of land wealth among 
rural households which has increased at a slower rate, rising by five percentage points. Women's share of financial savings among urban households increased from 29 per cent in 1991/1992 to 32 per cent in 2005/2006 and 2012/13 despite the dip in 1998/1999. Women's share of financial savings among rural households followed a more uneven pattern but is substantially higher in 2012/2013 (28\%) than in 1991/1992 (10\%). For urban households, women's share of business wealth has declined over the period. This is driven primarily by a small number of men in urban areas who have accumulated relatively large business enterprises.

\section{Women's Share of All Assets Owned in 2010}

We now turn to a discussion of women's share of asset wealth using the GAGP data that includes individual asset ownership information on all assets owned by anyone in the household. The advantage of the GAGP data set is that it allows analysis by sex over a broader range of assets, however it is only available for 2010 . Thus, it allows us to consider whether land, business assets, and savings are typical of the patterns across a wider range of assets.

Women own a smaller share of asset wealth than men across all asset types (Figure 2), not just land, businesses and savings. Overall, women own 30.2 per cent of household gross physical wealth. The numbers for land, savings and business assets are roughly comparable with those from the GLSS analysis for 2012/2013.

The assets for which women own a relatively higher share of household wealth are housing, businesses, consumer durables, and savings. These are also assets whose share of household wealth overall is increasing over time. This suggests that if we do not include analysis of these assets, we will miss key components of the unfolding story on the gendered pattern of asset ownership. 
The fact that women own a relatively small proportion of agricultural land, agricultural equipment, and livestock is consistent with the concerns articulated in the literature on agricultural productivity, which suggests that women have less access to key agricultural inputs (Peterman et al., 2014; Doss et al., 2015; Kieran et al., 2015). While women could potentially access land for farming without owning it, these data suggest that the value of the agricultural land that women own is much less than that owned by men.

With this data that includes a wider range of assets, we can also consider the extent to which poor women are disproportionately disadvantaged in their asset ownership. For each asset category, Figure 3 presents women's share of the value of those assets by welfare quintile. ${ }^{\text {vii }}$

Women's share of housing wealth and livestock wealth increases by quintile. While women in the lowest quintile own 29 per cent of the housing in value terms, in the richest households, women own a higher fraction of the housing wealth, at 42 per cent.

For the other assets, the pattern is less clear. Women's share of business wealth, consumer durables and agricultural equipment is lower in the fourth and fifth quintiles than it is in the other quintiles. This is because men in the fourth and fifth quintiles own much larger businesses than women, even though the incidence of business ownership is higher for women. Similarly, women's share of the ownership of consumer durables and agricultural equipment declines by quintile because men in the fourth and fifth quintiles are more likely to own the more expensive consumer durables and large equipment. No clear patterns by quintile emerge for women's share of agricultural land wealth and their share of other real estate wealth, although women's share of these assets is higher in the fifth quintile than in the lowest quintile. Among the poorest three quintiles, women's share of wealth is highest for businesses and consumer 
durables. In the fourth quintile, consumer durables and the place of residence have the highest shares of women's wealth, whilst in the fifth quintile it is the place of residence and businesses.

\section{Explaining the Gender Patterns}

Of the three assets for which information on women's share is available over time, their share of asset wealth has risen. Yet women still own a relatively low share of total wealth.

One way that people acquire assets is through the market. Yet women continue to be disadvantaged in their earnings. Many women continue to work unpaid on farms or enterprises owned by family members and this share is higher in 2010 (14.4\%) than in 2000 (7.8\%) (Ghana Statistical Service, 2013). In the paid labour sectors, women's wages still lag behind men's and the situation is getting worse, not better. In 1991/1992 the ratio of women's to men's basic hourly wage was 0.87 (Ghana Statistical Service, 1995). It declined to 0.69 in 1998/1999 (Ghana Statistical Service, 2000) and to 0.66 in 2012/2013 (Ghana Statistical Service, 2014). This evidence suggests that women's capacity to purchase assets has lagged behind that of men's.

The geographical spread of cities has contributed to the emergence of land markets. viii These markets provide women the opportunity to purchase land if they have the means. It may be easier for women, particularly urban women who will have higher incomes than rural women, to acquire land through purchase than through inheritance.

There is evidence that in some parts of the country inheritance practice is becoming more inclusive and women do inherit these assets (Oduro et al., 2010, 2011). Fathers and spouses in matrilineal communities may get around the traditional barriers placed on the inheritance of a man's property by his wife and children by gifting these assets to them (Amanor, 2001;

Quisumbing et al., 2001). We find that women owners are more likely than men owners to have 
acquired agricultural land, the place of residence and other real estate as gifts (Oduro et al, 2011).

Both the GLSS and GAGP data sets reveal that women's share of asset wealth is highest for financial savings. Cultural constraints on women's ownership of these assets are less severe. A major constraint for women would be their ability to earn incomes large enough to build up their financial savings. Yet, this is a hopeful sign that women may benefit through structural transformation.

\section{Conclusions}

The composition of assets held by households has changed over this recent period of rapid economic growth in Ghana. Consistent with the changes that happened over a much longer period of structural transformation in Europe and the US, the share of land has decreased in household portfolios and the share of housing has increased.

Increases in incomes and urbanization have happened relatively quickly. Unlike in the historical periods in the industrialized countries, the availability of consumer goods in Ghana has expanded fast. Thus, we see a fairly rapid increase in the value of consumer durables held by households. Yet, some of the other changes have been slower to materialize. While the share of financial assets is growing, it is still relatively small.

Women's share of asset ownership relative to men's has increased as the historical pattern would have suggested. Although social norms can transform rapidly, it is not surprising that women have not benefitted as much from the new opportunities as might have been possible. Changes in inheritance practices, in particular, may happen more slowly than other economic changes. We see women's share of assets growing particularly among those assets that are 
becoming a relatively larger proportion of the household wealth portfolio. This suggests that policies should work to ensure that as these opportunities for asset ownership increase, women are well placed to take advantages of them.

Finally, it is worth noting that data on the value of assets collected in household surveys tends to be noisy. We might expect that this is especially true during rapid economic changes, where the values of assets may change quickly. We have shown that the incidence of ownership of some assets, particularly housing, financial assets, and consumer durables have increased. With data at four time periods, we do see the overall trends that we would expect, but it is not necessarily linear trends between any two years. There are some anomalies in the patterns for a particular asset in a particular year. This suggests that one should be cautious about interpreting trends based on only two data points. 
Table 1. Structure of Output and Employment 1990-2013

\begin{tabular}{lrrr}
\hline Structure of Production & 1990 & 2000 & 2012 \\
\hline Agriculture (\%) & 45.1 & 39.4 & 23.6 \\
Industry (\%) & 16.9 & 28.4 & 28.9 \\
$\quad$ Manufacturing (\%) & 9.8 & 10.1 & 6.0 \\
Services (\%) & 38.1 & 32.2 & 47.5 \\
& & & \\
\hline Composition of & & & \\
Employment & 1992 & 1999 & 2013 \\
\hline All & & & \\
$\quad$ Agriculture (\%) & 62 & 55 & 44.7 \\
Industry (\%) & 10.1 & 14 & 14.4 \\
$\quad$ Services (\%) & 27.9 & 31.1 & 40.9 \\
Women & & & \\
$\quad$ Agriculture (\%) & 58.7 & 50.3 & 41.4 \\
Industry (\%) & 9.8 & 14.5 & 11.3 \\
$\quad$ Services (\%) & 31.9 & 35.6 & 47.3 \\
Men & & & \\
$\quad$ Agriculture (\%) & 66.2 & 59.8 & 48.2 \\
Industry (\%) & 10.4 & 13.5 & 17.8 \\
$\quad$ Services (\%) & 23.1 & 26.5 & 34.0 \\
\hline So: Worl Ba
\end{tabular}

Source: World Bank, World Development Indicators

Table 2. Composition of Household Asset Wealth over Time (\%)

\begin{tabular}{lrrrr}
\hline & $1991 / 1992$ & $1998 / 1999$ & $2005 / 2006$ & $2012 / 2013$ \\
\hline Land & 35.3 & 28.5 & 25.6 & 22.9 \\
Housing & 31.7 & 24.0 & 35.4 & 38.8 \\
Other real estate & 13.7 & 16.3 & 15.4 & 9.6 \\
Consumer durables & 9.0 & 9.2 & 11.8 & 13.0 \\
Business assets & 4.0 & 6.5 & 3.5 & 3.3 \\
Livestock & 3.8 & 10.7 & 3.7 & 5.4 \\
Ag. equipment & 0.6 & 2.7 & 1.2 & 1.7 \\
Savings & 1.7 & 1.8 & 3.3 & 5.2 \\
Shares & 0.2 & 0.2 & 0.1 & 0.2 \\
Total & 100.0 & 100.0 & 100.0 & 100.0 \\
\hline
\end{tabular}

Source: Calculated by authors from GLSS data. 
Table 3. Composition of Household Wealth over Time, by Location (\%).

\begin{tabular}{|c|c|c|c|c|c|c|c|c|}
\hline & $\begin{array}{l}1991 / \\
1992\end{array}$ & $\begin{array}{r}1998 / \\
1999 \\
\end{array}$ & $\begin{array}{r}2005 / \\
2006 \\
\end{array}$ & $\begin{array}{r}2012 / \\
2013 \\
\end{array}$ & $\begin{array}{r}1991 / \\
1992 \\
\end{array}$ & $\begin{array}{r}1998 / \\
1999 \\
\end{array}$ & $\begin{array}{r}2005 / \\
2006 \\
\end{array}$ & $\begin{array}{r}2012 / \\
2013 \\
\end{array}$ \\
\hline & \multicolumn{4}{|c|}{ Urban } & \multicolumn{4}{|c|}{ Rural } \\
\hline Land & 10.0 & 7.4 & 7.2 & 9.6 & 50.0 & 38.8 & 40.9 & 43.7 \\
\hline Housing & 53.7 & 40.8 & 57.7 & 49.9 & 19.1 & 15.9 & 20.3 & 21.4 \\
\hline Other real estate & 7.6 & 11.4 & 7.7 & 9.2 & 17.1 & 18.6 & 21.8 & 10.2 \\
\hline Business assets & 5.9 & 13.3 & 6.5 & 4.4 & 2.9 & 3.2 & 1.0 & 1.5 \\
\hline Livestock & 1.3 & 5.5 & 1.1 & 2.0 & 5.2 & 13.2 & 5.8 & 10.9 \\
\hline $\begin{array}{l}\text { Agricultural } \\
\text { equipment }\end{array}$ & 0.5 & 1.8 & 0.5 & 1.3 & 0.6 & 3.5 & 1.8 & 2.3 \\
\hline Financial assets & 3.4 & 3.2 & 3.5 & 7.9 & 1.1 & 1.5 & 3.2 & 2.9 \\
\hline Consumer durables & 17.6 & 17.2 & 19.7 & 16.7 & 4.0 & 5.3 & 5.3 & 7.1 \\
\hline Total & 100.0 & 100.0 & 100.0 & 100.0 & 100.0 & 100.0 & 100.0 & 100.0 \\
\hline
\end{tabular}

Source: Calculated by authors from GLSS.

Table 4. Share of Asset Wealth held by Women over Time and by Location (\%)

\begin{tabular}{lcccc}
\hline $\begin{array}{l}\text { Form of } \\
\text { wealth }\end{array}$ & $1991 / 1992$ & $1998 / 1999$ & $2005 / 2006$ & $2012 / 2013$ \\
\hline Ghana & 12.9 & 20.5 & 15.9 & 22.0 \\
Land & 22.3 & 27.7 & 26.9 & 31.6 \\
Savings & 22.4 & 23.3 & 22.3 & 25.2 \\
Business & 14.2 & 21.3 & 17.4 & 23.9 \\
Total & & & & \\
& & 24.5 & 30.3 & 33.4 \\
Urban & 9.1 & 26.0 & 32.4 & 32.3 \\
Land & 29.1 & 15.8 & 21.6 & 23.4 \\
Savings & 30.0 & 19.7 & 27.4 & 30.9 \\
Business & 18.8 & & & \\
Total & & & & \\
& & 20.1 & 13.7 & 18.2 \\
Rural & 13.2 & 29.3 & 17.3 & 28.4 \\
Land & 10.1 & 38.3 & 26.8 & 32.7 \\
Savings & 13.2 & & &
\end{tabular}


Source: Calculated by authors from GLSS.

Figure 1. Value of Crop/pasture Land as a Share of Total Wealth, 2005.

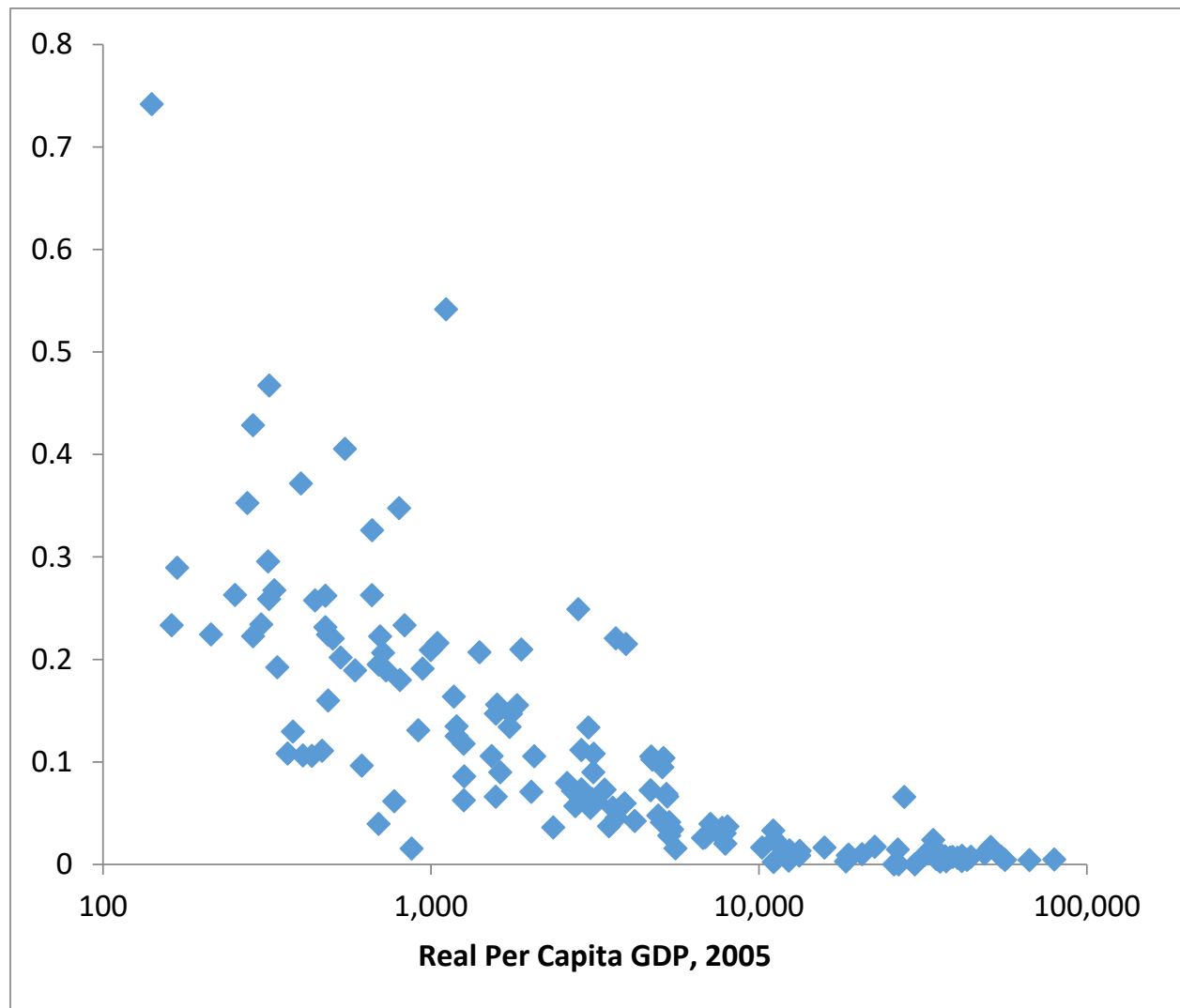

Source: Calculated using the World Bank wealth of nations data. http://data.worldbank.org/data-catalog/wealth-of-nations 
Figure 2: Women's share of Gross Household Asset Wealth, 2010 (\%)

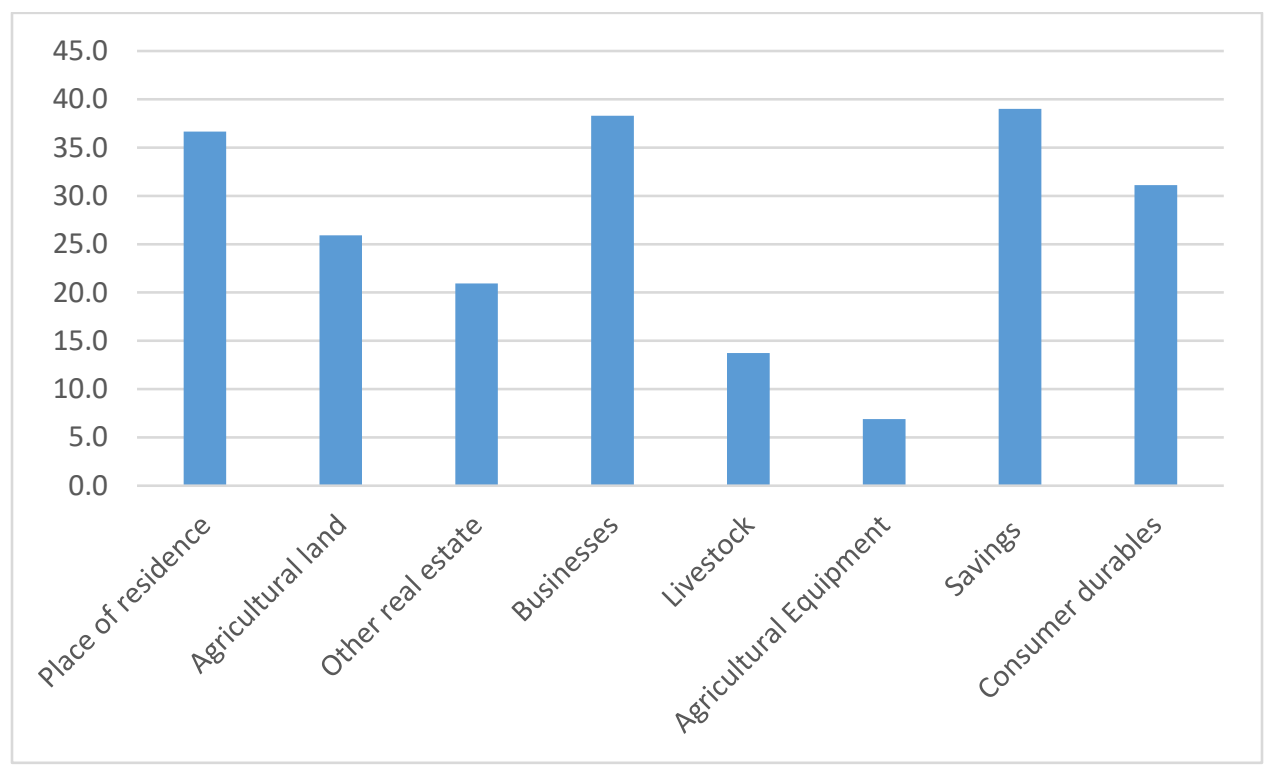

Source: Authors' calculations from GAGP data. 
Figure 3: Women's Share of Gross Household Asset Wealth by Asset and Welfare Quintile, $2010(\%)$

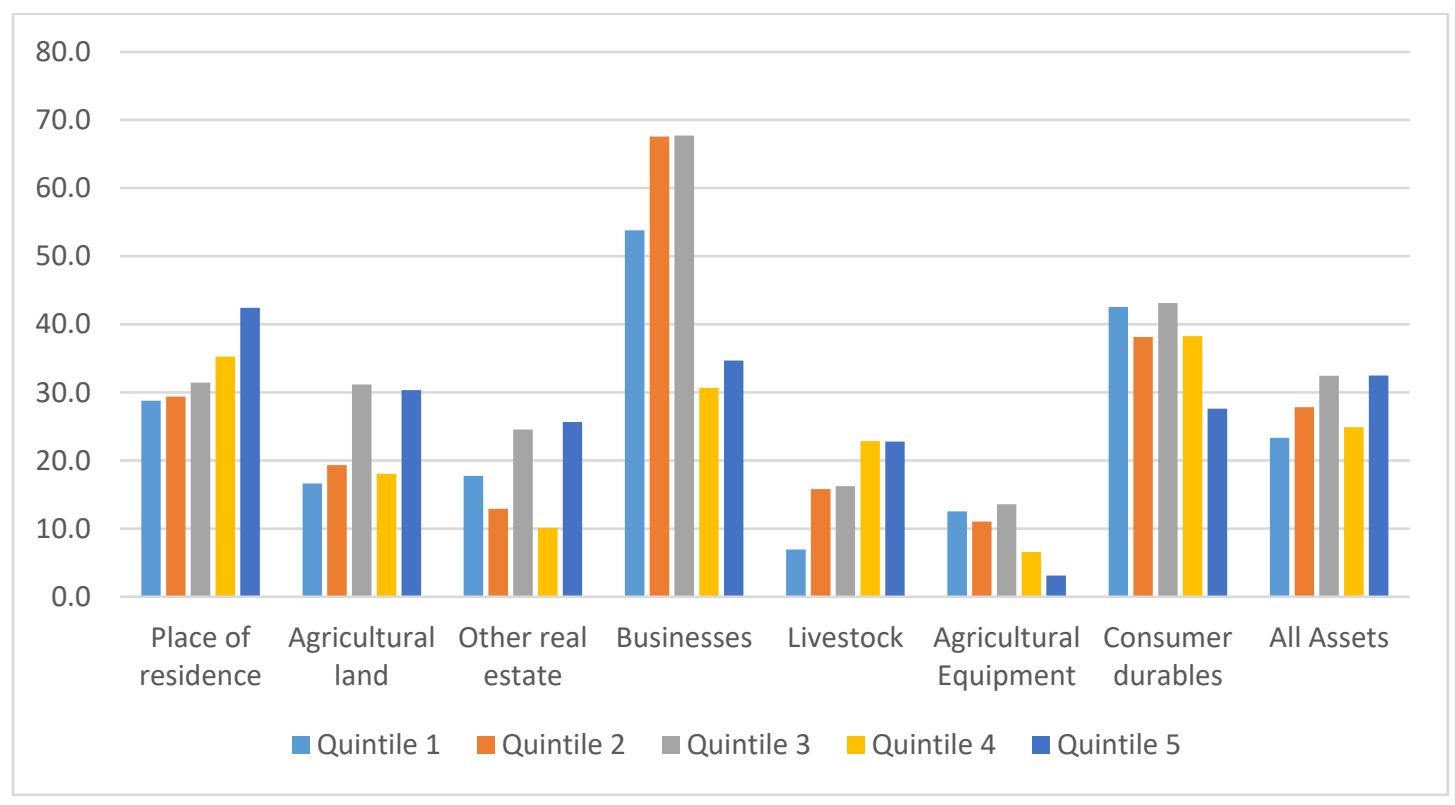

Source: Authors' calculations from GAGP data.

\footnotetext{
${ }^{\mathrm{i}}$ Note that urbanization is not necessarily the same as a change in the structures of production; in principle, it is possible for movements out of agriculture to take the form of rural non-farm activities.

ii In 1970, 54 per cent of employed women and 59 per cent of employed men worked in the agriculture sector. The share of employed women and men employed in the wholesale and retail trade was 26.1 per cent and 3.9 per cent respectively.

iii We do not use the first two rounds of the GLSS survey because the questions are different enough to make the data less comparable across time.

iv The GAGP has detailed information on indebtedness for a maximum of two adult members of the household.

${ }^{v}$ We tried several methods to deal with outliers, including winsorizing the data, but the patterns did not substantially change.

vi The housing price index produced by the Ghana Statistical Service, which includes utility prices increased by 42 per cent, 27 per cent and 64.3 per cent in 2001, 2002 and 2003

respectively compared to 91-day Treasury bill rates of 29 per cent, 26 per cent and 20 per cent.
} 


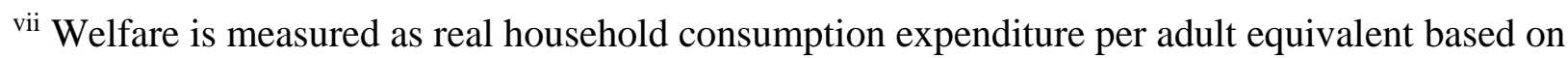
consumption data collected through the GAGP.

viii Between 1986 and 1987, the capital city, Accra, expanded by 171.9 square miles (Yeboah, 2003). 


\section{References:}

Allendorf, K. (2007). Do women's land rights promote empowerment and child health in Nepal? World Development, 35, 1975-1988.

Amanor, K. S. (2001). Land, labour and the family in Southern Ghana: A critique of land policy under neo-liberalisation. (Research Report no.116). Uppasala: Nordiska Afrikainstitutet.

Bank of Ghana. (2012, March). Statistical Bulletin. Accra.

Combs, M. B. (2006). Cui Bono? The 1870 British married women's property act, bargaining power and the distribution of resources within marriage. Feminist Economics, 12(1-2), 51-83.

de Vries, G., Timmer, M., \& de Vries, K. (2015). Structural transformation in Africa: Static gains, dynamic losses. The Journal of Development Studies, 51, 674-688.

Deere, C. D., \& Díaz, C. J. (2011). Acumulación de Activos: Una apuesta por la equidad. [Asset Accumulation: The challenge for equity]. Quito, Ecuador: FLACSO.

Deere, C. D., \& Doss, C. R. (2006). The gender asset gap: What do we know and why does it matter? Feminist Economics, 12(1-2), 1-50.

Deininger, K., Goyal, A., \& Nagarajan, H. (2013). Women's inheritance rights and intergenerational transmission of resources in India. Journal of Human Resources, 48(1), 114-141.

Demirguc-Kunt, A., Klapper, L., Singer, P., \& Oudheusden, P. (2015). The Global Findex Database 2014: Measuring financial inclusion around the world. (Policy Research Working Paper 7255). Washington, DC: World Bank.

Doss, C. (2006). The effects of intrahousehold property ownership on expenditure patterns in Ghana. Journal of African Economies, 15(1), 149-180.

Doss, C. (2013). Intrahousehold bargaining and resource allocation in developing countries. World Bank Research Observer, 28(1), 52-78.

Doss, C. R., Deere, C. D., Oduro, A. D., \& Swaminathan, H. (2014). The gender asset and wealth gaps. Development, 57, 400-409.

Doss, C., Kovarik, C., Peterman, A., A., Q., \& van den Bold, M. (2015). Gender inequalities in ownership and control of land in Africa: Myth and reality. Agricultural Economics, 46(3), 403-434.

Doss, C., Oduro, A. D., Deere, C. D., Swaminathan, H., Baah-Boateng, W., \& Suchitra, J. Y. (2017). Assets and shocks: A gendered analysis of Ecuador, Ghana and Karnataka, India. Canadian Journal of Development Studies / Revue canadienne d'études du développement, 1-18. 
Enache, M., Ghani, E., \& O'Connell, S. (2016). Structural Transformation in Africa. A historical view. (Policy Research Working Paper WPS7743). Washington, DC: World Bank.

Friedemann-Sánchez, G., \& Lovatón, R. (2012). Intimate partner violence in Columbia: Who is at risk? Social Forces, 91, 663-688.

Ghana Statistical Service. (1995). Ghana Living Standards Survey. Report on the third round (GLSS3). Accra.

Ghana Statistical Service. (2000). Ghana Living Standards Survey. Report on the fourth round (GLSS4). Accra.

Ghana Statistical Service. (2005). Population data analysis reports. Volume 1. Socio-economic and demographic trend analysis. Accra.

Ghana Statistical Service. (201). Population and housing census. National Analytical Report. Accra.

Ghana Statistical Service. (2014). Ghana Living Standards Survey. Round six (GLSS6). Main Report. Accra.

Ghana Statistical Service. (2015). Revised 2014 Annual gross domestic product. Accra. Retrieved May 21, 2016, from http://www.statsghana.gov.gh/docfiles/GDP/GDP2015/Annual_2014_GDP_Rev2_June 2015\%20edition.pdf

Gollin, D., Jedwab, R., \& Vollrath, D. (2016). Urbanization with and without industrialization. Journal of Economic Growth, 21(1), 35-70.

Gollin, D., Parente, S. L., \& Rogerson, R. (2002). The role of agricultural development. American Economic Review, 92 (2), 160-164.

Green, D. R., \& Owens, A. (2003). Gentlewomanly capitalism? Spinsters, widows and wealth holding in England and Wales, c. 1800-1860. The Economic History Review, 56, 510536.

Grown, C., Deere, C. D., Catanzarite, Z., Oduro, A. D., Suchitra, J. Y., Swaminathan, H., \& Boakye-Yiadom, L. (2015). Who borrows? An analysis of gender, debt and assets in Ghana, Ecuador and Karnataka, India. Retrieved from http://www.unwomen.org/en/digital-library/publications/2015/6/who-borrows-ananalysis-of-gender-debt-and-assets.

Keister, L. (2000). Wealth in America: Trends in wealth inequality. Cambridge, MA: Cambridge University Press.

Kieran, C., Sproule, K., Doss, C., Quisumbing, A., \& Kim, S. M. (2015). Examining gender inequalities in land rights indicators in Asia. Agricultural Economics, 46(S1), 119-138.

Ministry of Food and Agriculture. (2011). Agriculture in Ghana - Facts and Figures, 2010. Accra, Ghana: MOFA, Statistics, Research and Information Directorate. 
Oduro, A. D., Baah-Boateng, W., \& Boakye-Yiadom, L. (2010). Asset accumulation by women in Ghana. Understanding the process. (Working Paper No. 4). Bangalore: Gender Asset Gap Project. Retrieved from https://sites.google.com/view/genderassetgap/working-papers?authuser=0

Oduro, A. D., Baah-Boateng, W., \& Boakye-Yiadom, L. (2011). Measuring the gender asset gap in Ghana. Accra: University of Ghana and Woeli Publishing Services.

Oduro, A. D., Deere, C. D., \& Catanzarite, Z. (2015). Women's wealth and intimate partner violence: Insights from Ecuador and Ghana. Feminist Economics, 21(2), 1-29.

Osei, R. D., \& Jedwab, R. (2017). Structural change in a poor African country: New historical evidence from Ghana. In M. S. McMillan, D. Rodrick, \& C. Sepúlveda (Eds.), Structural change, fundamentals and growth: A framework and case studies (pp. 161-196). Washington, DC: International Food Policy Research Institute.

Panda, P., \& Agarwal, B. (2005). Marital violence, human development and women's property status in India. World Development, 33, 823-850.

Paxton, J. (2009). Subsistence saving strategies of male- and female-headed households: Evidence from Mexico. Eastern Economic Journal, 35(2), 209-231.

Peterman, A., Behrman, J. A., \& Quisumbing, A. R. (2014). A review of empirical evidence on gender differences in nonland agricultural inputs, technology and services in developing countries. In A. R. Quisumbing, R. Meinzen-Dick, T. L. Raney, A. Croppenstedt, J. A. Behrman, \& A. Peterman, Gender in Agriculture: Closing the Knowledge Gap (pp. 145186). New York, NY: Springer.

Quisumbing, A. R., Payongayong, E., Aidoo, J. B., \& Otsuka, K. (2001). Women's land rights in the transition to individualized ownership: Implications for tree-resource management in western Ghana. Economic Development and Cultural Change, 50(1), 157-181.

Rossi, M., \& Sierminska, E. (2015). Housing decisions, family types and gender. A look across LIS countries. (LIS Working Paper Series No. 654).

Rutterford, J., \& Maltby, J. (2006). "The widow, the clergyman and the reckless.": Women investors in England, 1830-1914. Feminist Economics, 12(1-2), 111-138.

Schmidt, L., \& Sevak, P. (2006). Gender, marriage and asset accumulation in the United States. Feminist Economics, 12(1-2), 139-166.

Shammas, C. (1993). A new look at the long-term trends in wealth inequality in the United States . The Ameican Historical Review, 98, 412-431.

Shorrocks, A. (1982). The portfolio compostion of asset holdings in the United Kingdom. The Economic Journal, 92(366), 268-284.

Swaminathan, H., Suchitra, J. Y., \& Lahoti, R. (2011). KHAS: Measuring the gender asset gap. Bangalore: Indian Institute of Management. 
UNDP. (2010). Human development report 2010. The real wealth of nations: Pathways to human development. New York: Palgrave Macmillan.

Wolff, E. N. (1998). Recent trends in the size distribution of household wealth. The Journal of Economic Perspectives, 12(3), 131-150.

World Bank. (2011). The changing wealth of nations: Measuring sustainable development in the new millenium. Washington, DC: World Bank.

Yeboah, I. (2003). Demographic and housing aspects of structural adjustment and emerging urban Accra, Ghana. Africa Today, 50(1), 107-119. 